\title{
Technical and economic efficiency of bovine weighing methods
}

\section{Eficiência técnica e econômica de diferentes métodos de pesagem de bovinos}

\author{
Marcos Aurélio Lopes ${ }^{1 *}$; Juliana Aparecida Vieira ${ }^{2}$; Francisco Helton Sá de Lima ${ }^{3}$; \\ Fabiana Alves Demeu ${ }^{4}$; Fábio Raphael Pascoti Bruhn"; Adriano Pereira ${ }^{6}$; Fábio \\ Henrique Vicente ${ }^{7}$; Pedro Salermo Casas $^{7}$
}

\begin{abstract}
The objective of this study was to evaluate the technical and economic efficiency of different methods of cattle weighing, and to develop mathematical equations to estimate the breakeven point for the adoption of electronic weighing, i.e., to estimate how many animals are required for the acquisition and use of an electronic scale to be economically viable. The survey was conducted in confined beef cattle, from the Federal Institute of Education, Science and Technology in the south of Minas Gerais, IFSUL DE MINAS, Muzambinho Campus, from July to December 2014. Two methods of weighing cattle were evaluated: an electronic scale and a tape measure, using a barimetric tape for dairy cattle and a barimetric tape for beef cattle, and a conventional tape measure involving the conversion of centimeters into body weight using a specific table. Thirty-three animals identified with plastic ear tags were weighed using each method. Animals of the Nellore, Senepol, Girolando, and Red-angus breeds, aged $0-1,1-2$, and $2-3$ years, were weighed 402 times in total. The time taken to weigh animals with the electronic scale was the lowest, followed by that with the barimetric tape, and that with conventional tape measure with conversion. The electronic scale exhibited the greatest technical efficiency, owing to the lack of error and the lowest time required to weigh animals. However, the costs associated with the use of this equipment were the highest, which depended on the purchasing cost. The mathematical equations developed will help technicians and cattle farmers to rapidly and precisely estimate the minimum number of animals that should compose a production system to ensure economic viability for the adoption of an electronic method to weigh cattle.
\end{abstract}

Key words: Automation. Cattle raising. Animals handling. Morphometry. Precision animal science.

1 Prof. Titular, Departamento de Medicina Veterinária, Universidade Federal de Lavras, UFLA, Lavras, MG, Brasil. Bolsista do CNPq. E-mail: malopes@dmv.ufla.br

2 Discente, Curso de Graduação em Zootecnia, UFLA, Lavras, MG, Brasil. E-mail: juvieirau2@gmail.com

3 Prof., Instituto Federal de Educação, Ciência e Tecnologia do Sul de Minas Gerais, IFSULDEMINAS, Campus Muzambinho, Muzambinho, MG, Brasil. E-mail: francisco.lima@ifsuldeminas.edu.br

${ }^{4}$ Prof ${ }^{a}$, Instituto Federal de Educação Ciência e Tecnologia de Rondônia, IFRO, Bolsista Prodoutoral CAPES, Discente de Doutorado, UFLA, Lavras, MG, Brasil. E-mail: fabiana.demeu@hotmail.com

5 Prof., Universidade Federal de Pelotas, UFPEL, Departamento de Veterinária Preventiva. Capão do Leão, RS, Brasil. E-mail: fabio_rpb@yahoo.com.br

6 Técnico em Agropecuária, IFSULDEMINAS, Campus Muzambinho, Muzambinho, MG, Brasil. E-mail: adriano.pereira2016@ yahoo.com.br

7 Discentes, Curso de Graduação em Medicina Veterinária, UFLA, Lavras, MG, Brasil. E-mail: fabiohenriquevicente07@hotmail. com; pedrosalermo@gmail.com

* Author for correspondence 


\section{Resumo}

Objetivou-se avaliar a eficiência técnica e econômica da implantação e utilização de diferentes métodos de pesagem de bovinos e desenvolver equações matemáticas que permitam estimar o ponto de equilíbrio para utilização do método eletrônico de pesagem, ou seja, estimar a partir de quantos animais é viável economicamente a aquisição e utilização da balança eletrônica. A pesquisa foi realizada no setor de gado de corte, em regime de confinamento, do Instituto Federal de Educação, Ciência e Tecnologia do Sul de Minas Gerais, IFSUL DE MINAS-Campus Muzambinho, no período de julho a dezembro de 2014. Foram avaliados dois métodos de pesagem de bovinos: balança eletrônica e fita métrica, sendo essa nas modalidades fita barimétrica para gado de leite e fita barimétrica para gado de corte e fita métrica convencional com conversão de centímetro em peso vivo (PV), utilizando-se tabela específica para essa finalidade. Cada método foi aplicado em 33 animais, identificados com brincos plásticos auriculares, das raças Nelore, Senepol, Girolando e Red-angus, com diferentes faixas etárias ( 0 a $1 ; 1$ a 2; 2 a 3 anos), sendo realizadas 402 pesagens. O tempo necessário para pesagem dos animais pelo método balança eletrônica foi o mais rápido, seguido pela fita barimétrica e fita métrica convencional com conversão de centímetro em tabela de PV. O método que apresentou maior eficiência técnica, em função de não ter apresentado erro e menor tempo gasto na pesagem dos animais, foi a balança eletrônica. No entanto, o custo da utilização deste equipamento foi o mais alto, principalmente em função do valor de sua aquisição. As equações matemáticas desenvolvidas auxiliam os técnicos e pecuaristas a estimar, com precisão e considerável rapidez, a quantidade mínima de animais que devem compor um sistema de produção para tornar economicamente viável a adoção do método eletrônico de pesagem animal.

Palavras-chave: Automação. Bovinocultura. Manejo de animais. Morfometria. Zootecnia de precisão.

\section{Introduction}

Livestock is associated with great social and economic importance in Brazil, and evidence indicates that this activity is growing in Brazil, both in terms of a producer of high-quality food, and as a source of foreign currency (CANESIN et al., 2007). The Brazilian cattle herd reached 212.3 million livestock units in 2014. With this, Brazil remained in second placed in the global ranking, with the second largest cattle herd in the world, behind only India (IBGE, 2014). Livestock is of fundamental importance for the Brazilian Agricultural Sector, considering that the activity is involved in the generation of income for many producers, and is also responsible for increasing the hiring the rural workforce (HOLANDA JÚNIOR; CAMPOS, 2003).

Recording and controlling information help the producer to make decisions that guarantee the best administrative performance. From this information, the periodic weighing of animals is important within a production system, as a measure of the zootechnical control. Lopes (1997) stated that this allows prompt and correct decision making when it comes to the management of several points. Data regarding average daily weight gain allow prior knowledge of termination time and allow the development of breeding systems that optimize production, reduce costs, and improve the quality of the final product. In addition, they lead to improved nutrition, the evaluation of feed efficiency, the exact determination of medication doses, and assessment of animal health status. Body weight can also be used to identify weak animals, improve the efficiency of replacement heifer creation, and establish income (REIS et al., 2008). Regarding genetic improvement, weighing is essential because, in selection programs, body size and measurements are directly related to animal weight. Morphometric measurements provide additional information that is useful for the determination of genetic trends and the phenotypic growth of animals over time (PACHECO et al., 2008).

The lack of mechanical and electronic livestock scales in farms reduces the ability of some producers 
to monitor the development of animals and adapt management. To minimize such deficiency, tape measures can be used to predict body weight by means of a model that includes measures (LOPES; VIEIRA, 1998). This requires more time and, consequently, a larger workforce, compared with the electronic method, which in turn requires higher investment. Therefore, a more efficient, reliable, and economically viable method is required.

Considering the different types of management and the possible use of equipment, the importance of weighing animals, which can be performed by different methods, and the lack of research that addresses this issue, especially the economic aspect, shows that further studies are needed. Thus, the objective of this study was to evaluate the technical and economic efficiency of different methods of cattle weighing, and to develop mathematical equations that allow the breakeven point to be estimated for the use of electronic weighing, i.e., to estimate how many animals are economically viable for the acquisition and use of an electronic scale. Specifically, the efficiency of different weighing methods was compared to evaluate the positional effect of animal members at the time of weighing, with barimetric tape. In addition, some advantages and limitations of each method are discussed to enables technicians and cattle farmers to choose the most efficient method of weighing cattle.

\section{Materials and Methods}

The research was carried out in the confined beef cattle sector, from the Federal Institute of Education, Science and Technology in the south of Minas Gerais, IFSUL DE MINAS, Muzambinho Campus, from July to December 2014. Two weighing methods were evaluated: an electronic scale and a tape measure, with a barimetric tape for dairy cattle and a barimetric tape for beef cattle, and a conventional tape measure that requires conversion of centimeters to body weight, using a specific table (LOPES; VIEIRA, 1998), four treatments were evaluated as follows: $\mathrm{T} 1=$ electronic scale, $\mathrm{T} 2=$ barimetric tape for dairy cattle, $\mathrm{T} 3$ =barimetric tape for beef cattle, and T4=tape measure. Each method was applied to 33 animals, which were identified with plastic ear tags. Animals of the breeds Nellore, Senepol, Girolando, and Red-angus, and aged 0-1, 1-2, and 2-3 years were used. In total, animals were weighed 402 times.

In order to standardize the process, detailed instructions were provided and researchers were trained on the use of the electronic livestock scales and tapes before the weighing procedures were initiated. For data collection and animal management, the team included six people: two to record the animal weighing time, one to record the data, and three to manage the animals in the trunk, cattle crush, as well as the weighing. The weighing procedures were performed by the same researcher, in order to avoid any influence at the time of weighing. The researcher read the weight on an electronic scale, measured the thoracic perimeter of the animal, and read the weight obtained by the tape. Two researchers recorded the time, using two stopwatches, to decrease the chance of error. The stopwatches began timing when the cattle were led to the cattle chute, continued timing during the entire weighing procedure, and were only stopped after notes had been made in the field book and the animal had completely left the trunk, as recommended by Lopes et al. (2013).

Animals were taken to the management stable and, from there, to the collective trunk, for subsequent weighing. Recommended "rational management" was followed, as developed through the study of animal behavior to promote more efficient management, using the behavioral characteristics of animals and respecting their senses (rational management), with the goal of minimizing damage and stress to cattle and humans (BARBALHO, 2007). The animals were weighed considering the four treatments. The order in which each treatment was performed was changed each day at random. A specific field notebook for data 
annotation was used for each treatment.

When animals were weighed using the electronic scale, they were moved from a handling corral to a collective trunk and then to the containment trunk, where an electronic scale was installed (COIMMA $\left.{ }^{\circledR}\right)$. After weighing the scale, each animal was weighed individually. After the beep that indicated the weight was stabilized, the researcher recorded the reading in the specific field book.

A similar procedure was used to weigh animals using barimetric tape, including both the tape for dairy cattle and the tape for beef cattle. The animal was contained in the trunk and then a researcher measured the thoracic perimeter using the tape. To measure the thoracic perimeter, the tape was placed around the chest, passing around the part of the bovine where the saddle is fitted and turning back perpendicular to the line of the animal's dorsum, as recommended by Pacheco et al. (2008). The researcher read the weight and then recorded it in the specific field book.

When weighing with a tape measure, the procedure was the same as that used for weighing with barimetric tape, except when the stopwatches were interrupted, which occurred after the conversion of the measurement in $\mathrm{cm}$ into body weight using the conversion table proposed by Lopes and Vieira (1998). The researcher read and recorded the weight.

For each animal weighed with tape, the position of the head and lower members was recorded to evaluate the influence of animal position on weight. The following options were considered: aligned members, non-aligned members, correct head, head down, and head up. This is justified because, according to the companies that sell the tapes, the animals must have their lower members lined up and their head in the normal position at the time of weighing for greater precision.

In order to evaluate the economic feasibility of each method, the operational cost methodology used by Lopes et al. (2013) was adopted, considering the expenditure on workforce, i.e., the value of the hours paid to workers involved in the activity, from the total of added hours necessary for weighing with each method, and the depreciation of the equipment used in weighing, considering that the electronic scale and the tapes will be used in several production cycles. In this study, no other materials made up the total operating cost, and only the depreciation was considered; this was estimated using the straight-line method (HOFFMANN et al., 1981). Based on these values, an economic feasibility analysis of investment was performed for the purchase of electronic scale, by estimating the net present value (NPV), the internal rate of return (IRR), and the payback, as described by Casarotto Filho and Kopittke (2010). In order to estimate these values and to calculate the cash flow, the investment in the electronic scale $(\mathrm{R} \$ 8,000,00)$ was considered an output and, the economy in work force when using the electronic equipment was the input. That is: the quantity of animals that should be weighed to make the purchase of the electronic scale economically viable will be defined in terms of annual depreciation of an electronic scale, the value spent on labor involved in weighing an animal using the tape method and the electronic scale method.

Using the studies of Lopes et al. $(2012,2017)$ as a reference, mathematical equations were developed. From these, we can estimate the minimum number of animals necessary for the electronic weighing method to be economically viable in the management of the cattle production system, and the number of times that animals should be weighed over 1 year, depending on the system of production.

To assess the differences in time spent (seconds) and the error (\%) in successive weightings performed using barimetric tape in dairy and beef cattle, and conventional metric, compared with the electronic scale (error of weighing, \%) (dependent variables) between cattle and different age (0-1;1-2; 2-3 years) and genetic groups (Nelore, Red Angus, and Senepol) (independent variables), in addition to the interaction between these factors, analyses of 
variance (ANOVA) with three factors, followed by multiple comparison test of Bonferroni correction were performed. It was the ANOVA regardless of the violation of the test assumptions, due to its high robustness (ability to maintain the test power), when the sample is large enough and balanced among the treatments (PESTANA; GAGEIRO, 2010). For each model of ANOVA, a minimum test power $(>0.8)$ was observed, in order to ensure confidence in the results of the analysis, as well as the measurement of the correlational effects, i.e., the fraction of the total variability of the dependent variable that is explained by the factor under study, by means of the partial Eta ${ }^{2}$ (MAROCO, 2010).

Comparisons of the different head positions (correct position, downward, or upward) and members (aligned or misaligned), in relation to the error (\%) associated with use of barimetric tape in beef cattle, dairy cattle, and conventional measures were made, by means of ANOVA and Student's t- test, after verifying the normality of the data distribution the variable error (\%) between the categories of head and member positions. To analyze the relationship between the weight $(\mathrm{kg})$ measured by the barimetric tapes (dairy and beef cattle) and the conventional metric, in relation to the electronic scale, Spearman tests were performed. A minimum confidence level of $95 \%$ was considered. The database was constructed and statistical analyzes were performed using the software SPSS ${ }^{\circledR} 20.0$ (IBM SPSS, 2011).

\section{Results and Discussion}

There was a significant difference $(\mathrm{P}<0.05)$ in the time spent weighing cattle between the electronic scale and tape methods, while the tape methods do not differ among themselves $(\mathrm{P}>0.05)$ (Table 1), with a size of partial $\mathrm{Eta}^{2}=0.294$; Maroco (2010) stated that this value can be considered average. The electronic scale was the most efficient method, and was on average 32.9 seconds faster than the barimetric tape, and 35.9 seconds faster than the measuring tape, permitting faster animal handling, with low workforce expenditure. There were no differences in time spent among the different genetic groups and the age ranges of evaluated bovine $(\mathrm{P}>0.05)$.

Table 1. Average time taken to weight cattle of different breeds*, using different methods.

\begin{tabular}{cc}
\hline Weighing method & Time (seconds) \\
\hline T1 $=$ electronic Scale & $35.2 \pm 16.5^{\mathrm{a}}$ \\
$\mathrm{T} 2=$ barimetric tape (dairy cattle) & $68.1 \pm 20.0^{* * \mathrm{~b}}$ \\
$\mathrm{~T} 3=$ barimetric tape (beef cattle) & $67.6 \pm 19.9^{* * \mathrm{~b}}$ \\
$\mathrm{~T} 4=$ conventional tape measure & $71.1 \pm 20.0^{* * * \mathrm{~b}}$ \\
\hline
\end{tabular}

*Nelore, Senepol, Girolando, and Red-angus. Age and breed were not significant in this ANOVA model $(\mathrm{P}>0.05)$.

** significant $(\mathrm{P}<0.05) * * *$ and $(\mathrm{P}<0.01)$ by ANOVA followed by Bonferroni tests. Means followed by the same letter do not differ among themselves.

Regarding the time taken to determine weight with tapes, the use of an American fixed containment trunk $\left(\right.$ COIMMA $\left.^{\circledR}\right)$ at the time of weighing should be considered, as it facilitates management, since this type of trunk allows complete animal immobilization. The possibility of completely immobilizing the animal promotes the use of tapes for weighing management, especially when animals of zebu breeds are handled, representing most animals in beef cattle production systems in Brazil. Fordyce et al. (1984) observed a more docile temper in taurine breeds compared with zebu animals. The use of this type of trunk may have favored the reduced weighing time with tape. When weighing 
with an electronic scale, according to Lopes (1997), there is no need for complete animal containment. When the weighing tapes are used for dairy cattle, with specialized breeds, such as the Dutch, management requires the use of a trunk, as these breeds are more docile. Therefore, the availability of a containment trunk during weighing increases management efficiency, especially when complete animal mobilization is necessary. Training staff how to weigh, use tapes, and convert centimeters into body weight, may also have positively influenced the weighing time. Although there was no significant difference, the time taken to use the tape measure may have been numerically high due to consultation with the table when converting centimeters to live bodyweight.

Animals were weighed with a specific barimetric tape for dairy and beef cattle. In a study on the prediction of body weight from body measurements in mongrel Dutch animals, Gir and Kings, Reis et al. (2008) found that animal weight can be estimated by a model that includes body measurements, with the thoracic perimeter as an explanatory variable that contributes most to the adhesion of the model. According to Pacheco et al. (2008), there is a high correlation between the thoracic circumference and weight $(\mathrm{r}=0.97)$, and those authors suggest using this measure as an estimate of animal body weight, which indicates that race influenced the occurrence of error.

In a study on morphometric measurements, Pacheco et al. (2008) found a high and favorable correlation between body weight and thoracic circumference, making its use possible, with tape as a method to estimate the animals' thoracic perimeter. Pacheco et al. (2008) also found that the correlation between morphometric measurements (objective measures) and the thoracic perimeter was high and significant $(\mathrm{P}<0.01)$, ranging between 0.76 and 0.98 , when it represented the thoracic perimeter in Guzera bulls and the weight found with tape was highly correlated with that observed on a mechanical balance (0.98).
Use of barimetric tape in beef cattle was not statistically correlated with any other method of weight determination. Using Spearman correlation, a significant positive correlation was found between barimetric tape in dairy cattle $(\mathrm{P}=0.007 ; \mathrm{r}=0.237)$, and conventional metrics $(\mathrm{P}=0.032 ; \mathrm{r}=0.189)$ and the electronic scale. A significant correlation was also observed between barimetric tapes for dairy cattle and conventional metrics $(\mathrm{P}=0.000 ; \mathrm{r}=0.475)$.

A weak correlation was found between barimetric tape for dairy cattle and a conventional tape measure, and between these and the electronic scale. Significant results $(\mathrm{P}<0.01)$ were also found by Pacheco et al. (2008), when correlating animal weight measured in conventional scales and that obtained with barimetric tape; however, in addition to being significant, the correlation was also high, ranging from 0.76 to 0.98 , which differs from the results of the present study, in which a weak correlation was observed. This difference may be due to the use of an electronic scale, which is more precise than the mechanical livestock scale, as used by the aforementioned authors. Contreras et al. (2012) also showed a highly significant phenotypic correlation between body weight and all morphological characteristics studied $(\mathrm{r}=0.93$; $\mathrm{P}<0.001$ ), with the thoracic perimeter being the best indicator of body weight.

The mean difference (error) between the results obtained with the electronic scale and the tapes was$10.82 \%( \pm 5.35)$, when considering all of the genetic groups studied (Table 2) The manufacturers of the barimetric tape note that the weighing error may be up to $\pm 5 \%$ (BOVITEC $\left.^{\circledR}\right)$.

Regarding the weighing efficiency (\%), significant differences were observed $(\mathrm{P}<0.01)$ between the weight obtained by barimetric tapes for dairy and beef cattle, and the weight obtained by electronic scale among the genetic groups, specifically between Red Angus (mean $=-12.2$ $\pm 5.1 \%$ ), Nelore (mean $=-9.6 \pm 5.1 \%$ ), and Red Angus and Senepol (mean $=-8.6 \pm 4.6 \%)$. The 
size of the effect of genetic group (partial $\mathrm{Eta}^{2}=$ 0.085) can be considered average (MAROCO, 2010), which indicates that despite genetic group influencing differences in cattle weighing, other factors not evaluated in the present study may have a greater influence on measurement errors in cattle weight when using tapes. There was no difference in the relative error between the different methods of weight measurement in terms of the electronic scale and age ranges of cattle evaluated $(\mathrm{P}>0.05)$.

Table 2. Relative error (\%) of weight measured with tapes and electronic scales.

\begin{tabular}{ccc}
\hline Tapes & Means & Standard deviation \\
\hline All tapes & -10.82 & $\pm \mathbf{5 , 3 5}$ \\
Barimetric tape (dairy cattle) & -10.78 & $\pm \mathbf{4 , 5 3}$ \\
Barimetric tape (beef cattle) & -10.52 & $\pm \mathbf{6 , 7 5}$ \\
Conventional tape measure & -11.16 & $\pm \mathbf{4 , 4 8}$ \\
\hline
\end{tabular}

Different results were observed by Mourão et al. (2010), who found no significant differences $(\mathrm{P}<0.05)$ between the genetic groups Nelore and F1 $\times$ Limosin for most of the assessments measured, and a significant difference $(\mathrm{P}<0.05)$ was found only for the length of the dorsum-loin and the cushion thickness. The appropriateness of genetic group in relation to the barimetric tape, which is specific to the fitness of each breed, whether dairy or beef, indicates that the objective is to decrease the difference among weights found regarding the electronic scale. The implication of this adaptation is due, especially, to the breed size, whether small, medium, or large. This information is contained in the tapes available on the market, which can cause differences in the values obtained for weights, if not answered such specification, which also decreases the weighing difference compared with an electronic scale. Heinrichs et al. (1992) noted that the weight regressions on body measurements and the accuracy of the estimate can be influenced by breed, age, body condition, and the physiological state of the animal. Understanding the limitations of weight measurements obtained with tapes will help in future decisions, including the interpretation of data collected by means of weighing tapes (HEINRICHS et al., 2007).
When the body weight obtained with the use of the tapes were analyzed, there was no significant difference $(\mathrm{P}>0.05)$ with that obtained by the electronic scale, in terms of the position of the head (mean $=10.7 \pm 4.2 \%$ ), whether it was down $($ mean $=9.0 \pm 3.4 \%)$ or upwards (mean= $11.6 \pm$ $6.0 \%)$, or between the members, whether aligned (mean $=10.5 \pm 4,0 \%$ ) or misaligned (mean $=9.8$ $\pm 4.6 \%$ ), at the time of weighing. This shows that it is not necessary to line up the front legs and no time should be invested in this practice, being an advantage, since it may decrease the weighing time with consequent labor economy.

In addition, there is a greater possibility of error when using a conventional tape measure, due to the need to use a table to convert centimeters into weight, since the barimetric tape already shows the animal weight without the need to consult the table. The use of the tapes is also associated with the possibility of error of weight annotating in the sheets or spreadsheets what, this research, did not occur. The electronic scale can increase the reliability of data collection throughout the weighing process, since weight is determined without the need for physical contact between the operator and the animal. Contrary to the use of barimetric tape, 
which also requires the person who is perming this handling, attention must be given to the use of an appropriate tape based on the genetic group or fitness of the animal. The use of tapes for weighing is associated with a lower purchase cost, but may require greater costs in terms of a workforce that can easily be trained. A limit of this method is the high number of errors; therefore, the reliability of such information is limited due to errors in the workforce or in the appropriate use of breeds for the barimetric tape or conversion table used.

Due to a lack of adequate equipment, many producers do not regularly weigh their animals. Many estimate animal weight based on visual appearance. Despite the only cost being that associated with the workforce, there is a high possibility of errors; this is because it is quite subjective and large differences can occur between the estimated and the actual weight. Mechanical scales have been used frequently in some production systems, while the use of electronic scales has been less frequent.

The depreciation of the fixed cost of electronic scales is high, which highlights the need for equipment optimization, as this cost is independent of the quantity of heavy animals. The higher cost of electronic equipment, involving animal precision
Zootechnics, according to Lopes et al. (2013), may make it use impossible in many settings. To make the use of electronic equipment viable, it is necessary to evaluate the technological level and quantity of animals, to ensure that the costs associated with the equipment can be "diluted " with the optimized use of the workforce. This demonstrates the importance of detailed studies on cost estimate, and the effective disbursements as well as equipment depreciation should be considered during the decision-making process. The higher the number of animals, the greater the annual depreciation of equipment will be diluted, with less representation in the unit cost. According to Lopes et al. (2006), an increase in the scale of production significantly influences the depreciation represented in the total fixed cost and total cost, by optimizing the infrastructure of the company. The values considered in this study are presented in Table 3. Electronic weighing of animals could be more profitable if associated with electronic identification and management of flockmonitoring software, eliminating reading errors that occur during the transcription of spreadsheets, individual sheets, and from typing, reducing the time taken to complete the task and increasing reliability, resulting in greater efficiency of the whole system.

Table 3. Acquisition values, and depreciation of equipment and materials used for weighing.

\begin{tabular}{ccccc}
\hline Materials used & $\begin{array}{c}\text { Purchase value } \\
(\mathrm{R} \$)\end{array}$ & $\begin{array}{c}\text { Annual rate of } \\
\text { depreciation (\%) }\end{array}$ & $\begin{array}{c}\text { Annual value of } \\
\text { depreciation (R\$) }\end{array}$ & Years \\
\hline Electronic scale & $8,000.00$ & 10.00 & 800.00 & 10 \\
Measure tape (dairy cattle) & 75.00 & 33.33 & 25.00 & 3 \\
Measure tape (beef cattle) & 75.00 & 33.33 & 25.00 & 3 \\
Conventional tape & 3.50 & 100 & 3.50 & 1 \\
\hline
\end{tabular}

Knowing the annual depreciation of an electronic scale, it is also important to know whether its purchase is economically viable. To estimate the minimum number of animals that should be weighed to ensure that the purchase of the equipment is economically viable, the equation developed by Lopes et al. (2017) was used as a reference, and adapted to form equation 1 (Eq. 1). Considering the difference between the amount spent on the workforce when determining animal weight by the tape and electronic scale methods, as well as the number of times that the animals will be 
weighed and the annual value of the depreciation of an electronic scale, the minimum quantity of animals that the cattle farmer must have to justify, economically, the electronic scale purchase was estimated. In other words, the equation developed is a function of the annual depreciation of an electronic scale, of the amount spent on the workforce, and the number of times that the animals are weighed during animal husbandry practice adopted in the production system.

$$
\begin{gathered}
\mathrm{QA}=\frac{\text { Annual depreciation of electronic scale }}{(\mathrm{M} 0 \text { tape method }-\mathrm{M} \text { electronic scale }) \times \mathrm{QP}} \text { (Equation 1) } \\
Q A=\frac{\mathrm{R} \$ 800,00}{(R \$ 0,0988-R \$ 0,0489) x 1}=16.032 \text { animals }
\end{gathered}
$$

$\mathrm{QA}=$ quantity of animals that should be weighed to ensure economicviability of the electronic scale purchase; MO method with tape $=$ value spent on the workforce involved in weighing animals using the method with tape, in R\$.

MO electronic scale $=$ value spent on the workforce involved in weighing animals using the method with electronic scale, in R\$.

$\mathrm{QP}=$ number of times that animals are to be weighed per year, depending on the management adopted during cattle raising.

In the present study, considering the average data collected in animals weighed with tape, electronic scale and the insertion of the respective values in equation 1 , the minimum number of animals needed to make the electronic scale purchase viable would be 16,043 , considering that the animals should be weighed at least once during the year. In production systems that require animals to be weighed more than once per year, the minimum number of animals needed to ensure the purchase of electronic scales is economically viable will be reduced. This equation will assist cattle farmers and technicians to estimate this, and permitting in decision-making.

Considering that the minimum number of weighed animals is a function of the annual depreciation of an electronic scale and the amount spent on workforce, the cattle farmer has some alternatives to reduce this amount. The main measure would be to reduce the purchase value of the weighing equipment, which will reflect the depreciation value, and may be obtained through market research (budgeting) (LOPES et al., 2013). Another crucial point that must be considered is the depreciation of weighing equipment. The value of the weighing electronics is far superior to that of the other materials. However, there are advantages when the animal weights are read, especially concerning the reliability of the information, as well as the reading time, which will be reflected in the reduced cost of the workforce.

To estimate the minimum number of animal weighings needed to make the purchase of an electronic scale economically viable, equation 2 was developed (Eq. 2). As with Eq. 1, the equation developed by Lopes et al. (2017) was taken as a reference and adapted. That is, considering the difference between the amount spent on the use of electronic scales, the difference between the amount spent on the workforce, in cases when animals were weighed by the conventional method and the electronic scale, the minimum number of times that animals need to be weighed was estimated to ensure the economic viability of adopting electronic scales. 


$$
\mathrm{QP}=\frac{\mathrm{COT} \text { annual of electronic scale per animal }- \text { COT annual of barimetric tape per animal }}{(\text { MO tape method }- \text { MO electronic scale })} \text { (Eq. 2) }
$$

$\mathrm{QP}=$ number of times that animals should be weighed, within a period of 1 year, depending on the production system of, to make the electronic scale purchase economically viable.

COT of electronic scale $=$ value of the operating cost of the electronic scale, in R\$.

COT method with tape $=$ value of the total operating cost associated with tape, in $\mathrm{R} \$$.

MO method with tape $=$ value spent on the workforce involved in animal weighing using tape, and note-taking in a field notebook, in R\$.

MO electronic scale $=$ value spent on the workforce involved in animalweighing using an electronic scale, in R\$.

$$
\begin{gathered}
Q P=\frac{0.0499-0.0014}{(\mathrm{R} \$ 0.0942-\mathrm{R} \$ 0.0489)}=1.07 \text { weighings } \\
\mathrm{QP}=\frac{0.0499-0.0002}{(R \$ 0.0988-R \$ 0.0489)}=0.9960 \text { weighings }
\end{gathered}
$$

After the insertion of the respective values into Eq. 2, the number of times that the animals should be weighed to ensure the economic viability of the electronic scale, replacing the different methods of weighing animals using tape, would be 1.00 and 1.07 for measuring and barimetric tape, respectively, in flocks with 16,032 and 17,660 animals, considering one weighing per year in the two methods. In production systems where animals are weighed more often, or when the flock includes a large number of animals, the economic viability of the electronic scale purchase will be reduced. In production systems where there is a need to weigh the animals with less frequency, or the number of animals in the herd does not enable the electronic scale to be purchased, the adoption of the barimetric tape or conventional tape measure can be of great benefit to the producers and technicians when monitoring animal performance.

The equations developed are important because, with the necessary data collected in their production system, cattle ranchers can estimate the minimum number of animals needed to make the purchase of an electronic scale economically viable, considering the number of successive weighings each year. These will be helpful for decision taking.

Some economic indicators were estimated (payback, or return time on invested capital; NPV, and IRR) for the investment made in an electronic scale comparing scenarios in which conventional methods of would be replaced by an electronic scale. Considering only the payback, and the animals being weighed once each year, the adoption of an electronic scale is justified with a minimum number of 16,032 animals, if the tape-measure method to is being replaced. If animals are weighed three times per year, the number of animals decreases to 5,344 (Table 4). The values are smaller when this method is used because, according to Lopes et al. (2013), it requires a larger workforce and more time. In relation to the barimetric tape methods, the minimum number of animals would be 17,660 and 5,887, respectively, when weighed one or three times per year. These results show that the higher the demand for labor, the more justified the automation. 
Table 4. Estimation of the net present value (NPV), internal rate of return (IRR), and payback(PB) of the investment made in an electronic scale comparing scenarios in which they replace different methods of weighing cattle.

\begin{tabular}{|c|c|c|c|c|c|c|c|}
\hline Scenarios & NPV (R\$) & IRR (\%) & PB (years) & Scenarios & NPV (R\$) & IRR (\%) & PB (years) \\
\hline & \multicolumn{7}{|c|}{1 weighing/year } \\
\hline \multicolumn{5}{|c|}{ Barimetric tape } & \multicolumn{3}{|c|}{ Tape measure } \\
\hline $17.660^{*}$ & $6,822.23$ & 0.0 & 10.0 & $16.032 *$ & $6,822.23$ & 0.0 & 10.0 \\
\hline $5.000 * *$ & $6,710.75$ & -18.1 & 34.4 & $5.000^{* *}$ & $6,715.14$ & -17.00 & 32.1 \\
\hline $10.000 * *$ & $6,754.84$ & -9.2 & 16.8 & $10.000 * *$ & $6,763.62$ & -7.8 & 16.1 \\
\hline \multirow[t]{3}{*}{$15.000 * *$} & $6,798.93$ & -2.8 & 11.10 & $15.000 * *$ & $6,812.09$ & -1.2 & 9.9 \\
\hline & \multicolumn{7}{|c|}{2 weighings/year } \\
\hline & \multicolumn{3}{|c|}{ Barimetric tape } & & \multicolumn{3}{|c|}{ Tape measure } \\
\hline $8.830^{*}$ & 6822.23 & 0.0 & 10.0 & $8.016^{*}$ & $6,822.24$ & 0.0 & 10.0 \\
\hline $5.000^{* *}$ & $6,754.84$ & -9.2 & 17.8 & $5.000^{* *}$ & $6,763.62$ & -7.8 & 16.1 \\
\hline $10.000 * *$ & $6,843.02$ & 2.3 & 8.9 & $10.000^{* *}$ & $6,860.57$ & 4.2 & 8.1 \\
\hline \multirow[t]{3}{*}{$15.000^{* *}$} & $6,931.19$ & 11.0 & 5.11 & $15.000^{* *}$ & $6,957.52$ & 13.4 & 5.4 \\
\hline & \multicolumn{7}{|c|}{3 weighings/year } \\
\hline & \multicolumn{3}{|c|}{ Barimetric tape } & \multicolumn{4}{|c|}{ Tape measure } \\
\hline $5.887^{*}$ & $6,822.23$ & 0.0 & 10.0 & $5.344 *$ & $6,822.25$ & 0.0 & 10.0 \\
\hline $5.000 * *$ & $6,798.93$ & -2.8 & 11.9 & $5.000 * *$ & $6,812.09$ & -1.2 & 10.8 \\
\hline $10.000 * *$ & $6,931.19$ & 11.0 & 5.11 & $10.000^{* *}$ & $6,957.52$ & 13.4 & 5.4 \\
\hline $15.000 * *$ & $7,063.45$ & 22.0 & 3.11 & $15.000 * *$ & $7,102.95$ & 25.0 & 3.7 \\
\hline
\end{tabular}

*Minimum quantity of animals; ** quantity of animals.

Thus, as the number of animals increases, the indicators of economic viability improve considerably, justifying the investment in technology. This is because the internal rates of return on capital were higher in scenarios involving 15,000 animals, compared with those involving 5,000 animals. In both scenarios, when animals are weighed three times per year, were higher than the minimum rate of attractiveness that, in this study, it was estimated at $6 \%$ per year (Table 4 ). Based on an investment analysis according to Casarotto Filho and Kopittke (2010), internal rates of return higher than the minimum rate of attractiveness indicate that the investment is economically viable.

The payback is considered the simplest known method for the economic evaluation of projects, which is be used to estimate the time necessary to recover the invested capital in a particular activity, regardless of the interest rate used (CONTADOR,
1997). In this study, the period required between the initial investment and the time at which the net accumulated profit equals the value of the investment will be 10 years, considering the electronic scale as an investment, and comparing with the barimetric tape. Compared with the measuring tape, the net profit equals the investment over 10 years, which consists of the lifetime of the electronic scale; 10 years, one weighing per year, and a minimum number of 16,032 and 17,660 animals, respectively.

IRR (Internal rate of return), which makes the present value of future profits equivalent to the expenditure of the project, and indicates the rate of return on capital invested (FRIZZONE; SILVEIRA, 2000 ), is $0.0 \%$ in both cases.

Considering the minimum number of animals that should be weighed to make the purchase of an electronic scale viable, the value of the VPL was R $\$ 6,822.23$ (Table 4), in both cases with the 
minimum number of animals. According to the VPL, the investment is economically viable and the investor will not lose any assets. The investment is profitable from the moment that the property contains a population of animals greater than the minimum number presented, because, in this case, the effective rate of return will be greater than the rate of return on an investment fixed in advance. The investment becomes viable as the number of animals weighed is increased, and the benefits of an electronic scale for the management of animals should be considered, as weight can be obtained without the necessity of contact at the time of weighing.

\section{Conclusions}

Among the methods analyzed, the electronic scale was found to have the highest technical efficiency, as less time is needed to determine animal weight, and the transcription of weight in a database is highly efficient, with no errors made, regardless of race and/or suitability (dairy or beef). However, the cost of utilizing the electronic method was higher, mainly due to the cost of purchasing the equipment.

Animal genetics influence the occurrence of errors when cattle are weighed using the barimetric tape method. This suggests that the barimetric tape for dairy cattle should be used considering the breeds, as well as the size of the breed, while the barimetric tape for beef cattle should be used to weigh breeds for meat production.

The mathematical equations developed should assist technicians and cattle farmers to estimate with precision and timeliness, the minimum number of animals that should compose a production system to ensure the economic viability of adopting an electronic method for animal weighing.

\section{Approval by the Ethics Committee in Animal Experimentation}

The experimental procedures were approved by the Ethics Committee in Animal Experimenting at the Federal University of Minas Gerais (Protocol CETEA 030/14).

\section{Acknowledgements}

The authors would like to thank the Minas Gerais State Research Foundation (Fundação de Amparo à Pesquisa do Estado de Minas Gerais -FAPEMIG), the National Council for Scientific and Technological Development (Conselho Nacional de Pesquisa e Desenvolvimento Tecnológico -CNPq) and Federal Institute of Education, Science and Technology in the south of Minas Gerais (Instituto Federal de Educação, Ciência e Tecnologia do Sul de Minas Gerais, IFSUL DE MINAS-Campus Muzambinho) for the financial support for the present study.

\section{References}

BARBALHO, P. C. Avaliação de programas de treinamento em manejo racional de bovinos em frigorificos para melhoria do bem-estar animal. 2007. Dissertação (Mestrado em Ciências Agrárias e Veterinária) - Universidade Estadual Paulista. Faculdade de Ciências Agrárias e Veterinárias, Jaboticabal.

CANESIN, R. C.; BERCHIELLI, T. T.; ANDRADE, P. A.; REIS, R. A. Desempenho de bovinos de corte mantidos em pastagem de capim-marandu submetidos a diferentes estratégias de suplementação no período das águas e da seca. Revista Brasileira de Zootecnia, Viçosa, MG, v. 36, n. 2, p. 411-420, 2007.

CASAROTTO FILHO, N.; KOPITTKE, B. H. Análise de investimento: matemática financeira, engenharia econômica, tomada de decisão e estratégia empresarial. São Paulo: Atlas, 2010. 472 p.

CONTADOR, C. R. Projetos sociais, avaliação e prática. São Paulo: Atlas, 1997. 375 p.

CONTRERAS, G.; CHIRINOS, Z.; MOLERO, E.; PAEZ, A. Medidas corporales e índices zoométricos de toros Criollo Limonero de Venezuela, Zootecnia Tropical, Maracay, v. 30, n. 2, p. 175-181, 2012. 
FORDYCE, G.; GODDARD, M. E. Maternal influence on the temperament of Bos indicus cross cows. Proccedings of the Australian Society of Animal Production, Wagga Wagga, v. 15, n. 2, p. 345-348, 1984.

FRIZZONE, J.A.; SILVEIRA, S. F. R. Análise econômica de projetos hidroagrícolas. In: SILVA, D. D.; PRUSKI, F. F. Gestão de recursos hídricos: aspectos legais, econômicos, administrativos e sociais. Secretaria de Recursos Hídricos, Brasília (DF). Universidade Federal de Viçosa e Associação Brasileira de Recursos Hídricos. Viçosa: Folha de Viçosa, 2000. p. 449-617.

HEINRICHS, A. J.; ERB, H. N.; ROGERS, G. W.; COOPER, J. B.; JONES, C. M. Variability in Holstein heifer heart-girth measurements and comparison of prediction equations for live weight. Preventive Veterinary Medicine, Colorado, v. 78, n. 3-4, p. 333-338, 2007.

HEINRICHS, A. J.; ROGERS, G. W.; COOPER, J. B. Predicting body weight and wither height in Holstein heifers using body measurements. Journal of Dairy Science, Madison, v. 75, n. 12, p. 3576-3581, 1992.

HOFFMANN, R.; ENGLER, J. J. C.; SERRANO, O.; THAME, A. G. de M.; NEVES, E. M. Administração da empresa agrícola. São Paulo: Pioneira, 1981. 325 p.

HOLANDA JÚNIOR, F. I. F.; CAMPOS, R. T. Análise técnico-econômica da pecuária leiteira no município de Quixeramobim -Estado do Ceará. Revista Econômica do Nordeste, Fortaleza, v. 34, n. 4, out./dez. 2003.

IBM SPSS Statistics for Windows. Manual del usuario del sistema básico de IBM SPSS Statistics 20. Version 20.0. Armonk: IBM Corporation, 2011.

INSTITUTO BRASILEIRO DE GEOGRAFIA E ESTATÍSTICA - IBGE. Censo agro completa primeira etapa com $93,6 \%$ das propriedades visitadas. Rio de Janeiro: IBGE, 2014. Disponível em: <http:// saladeimprensa.ibge.gov.br/>. Acesso em: 3 nov. 2014.

LOPES, M. A. Informática aplicada a bovinocultura. Jaboticabal: FUNEP, 1997. 82 p.

LOPES, M. A.; BARBOSA, G. L.; NOGUEIRA, T. M. Viabilidade econômica da terceira ordenha em sistemas de produção de leite com ordenha manual. Ciência Animal Brasileira, Goiânia, v. 13, n. 4, p. 412-420, 2012.
LOPES, M. A.; CARMO, E. A.; LIMA, A. L. R.; CARVAlHO, F. M. Análise da rentabilidade de uma empresa com opção de comercialização de queijo e leite. Arquivo Brasileiro de Medicina Veterinária e Zootecnia, Belo Horizonte, v. 58, n. 4, p. 642-647, 2006.

LOPES, M. A.; JUNQUEIRA, L. V.; BRUHN, F. R. P.; DEMEU, A. A.; SILVA, M. das D. Technical efficiency and economic viability of different cattle identification methods allowed by the Brazilian traceability system. Semina: Ciências Agrárias, Londrina, v. 38, n. 1, p. $467-$ 480, 2017.

LOPES, M. A.; SILVA, M. das D.; DEMEU, A. A.; GOMIDE, D. R.; BRUHN, F. R. P. Custo da implantação e utilização de dois métodos de identificação de bovinos leiteiros. Revista Ceres, Viçosa, MG, v. 60, n. 6, p. 757764, 2013.

LOPES, M. A.; VIEIRA, P. F. Criação de bezerros leiteiros. Jaboticabal: FUNEP, 1998. 69 p.

MAROCO, J. Análise estatística com o PASW Statistics. Pero Pinheiro: ReportNumber Ltda, 2010. 953 p.

MOURÃO, R. C.; RODRIGUES, V.C.; MOUSTACAS, V. S.; COSTA, D. P. B.; PINHEIRO, R. S. B.; FIGUEIREDO, M.; VIEIRA, A. O. Medidas morfométricas de novilhos castrados Nelore e $\mathrm{F}_{1}$ Nelore xLimousin. Agropecuária Cientifica no Semi-Árido, Campina Grande, v. 6, n. 1, p. 27-32, 2010.

PACHECO, A.; QUIRINO, C. R.; PINHEIRO, O. L. V. M.; ALMEIDA, J. V. C. Medidas morfométricas de touros jovens e adultos da raça Guzerá. Revista Brasileira de Saúde e Produção Animal, Salvador, v. 9, n. 3, p. 426435, 2008.

PESTANA, M. H.; GAGEIRO, J. N. Análise categórica, árvores de decisão e análise de conteúdo em ciências sociais e da saúde com o SPSS. Lisboa: Edições Lidel, 2010. $576 \mathrm{p}$.

REIS, G. L.; ALBUQUERQUE, F. M. A. R. A.; VALENTE, B. D.; MARTINS, G. A.; TEODORO, R. L.; FERREIRA, M. B. D.; MONTEIRO, J. B. N.; SILVA, M. A.; MADALENA, F. E. Predição do peso vivo a partir de medidas corporais em animais mestiços Holandês/Gir. Ciência Rural, Santa Maria, v. 38, n. 3, p. 778-783, 2008. 
